\title{
Winter flounder Pseudopleuronectes americanus reproductive success. I. Among-location variability in size and survival of larvae reared in the laboratory
}

\author{
L. J. Buckley, A. S. Smigielski, T. A. Halavik, E. M. Caldarone, B. R. Burns, \\ G. C. Laurence
}

National Marine Fisheries Service, Northeast Fisheries Center, Narragansett Laboratory, Narragansett, Rhode Island 02882-1199, USA

\begin{abstract}
Winter flounder Pseudopleuronectes americanus collected at selected locations in Long Island Sound (LIS), New York, and Narragansett Bay (NB). Rhode Island, USA, were spawned in the laboratory and the larvae reared for a month after hatching. [n 1987 the average size of yolk-sac larvae varied widely among locations. Moreover, a direct correlation was observed between size of yolk-sac larvae and survival for the first month of life. Fish from NB produced the smallest larvae with the lowest survival rate. The Madison site in LIS produced the largest yolk-sac larvae with the highest survival rate. Size and biochemical composition (ug larva ${ }^{-1}$ ) of yolk-sac larvae were correlated. Dry weight and RNA content were the best predictors of survival potential among the variables considered (protein, DNA, lipid content, and RNA/DNA ratio). In 1988 little difference was observed in viable hatch or weight of yolk-sac larvae among locations. While no significant difference in larval survival was observed between NB and LIS fish, survival was higher in the Madison group than the Morris Cove group from LIS. These data suggest that when differences in size among newly hatched larvae are sufficiently large, survival potential can be affected.
\end{abstract}

\section{INTRODUCTION}

Temperate marine fishes typically produce large numbers (thousands to millions) of small eggs (micrograms to milligrams dry weight). Survival through the embryonic and larval periods is low, frequently on the order of a few percent or less. Small changes in mortality rates during the early life stages can result in large and unpredictable changes in fish population abundance (Cushing 1975, Hunter 1981, Houde 1987).

Two potential contributors to differences in survival potential of individual eggs and larvae are size and biochemical composition. The embryos of most oviparous fishes are dependent upon material deposited in the developing oocyte to supply substrates for energy production and growth during the period from ovulation to initiation of feeding. Since a spawning fish has a finite amount of energy and metabolites to devote to reproduction, a balance must be achieved between size (mass) of an individual egg and the total number of eggs produced (Tanasichuk \& Ware 1987). While it is generally believed that larger larvae have a survival advantage over smaller larvae, direct experimental evidence supporting this assumption is limited (von Westernhagen 1988).

The winter flounder Pseudopleuronectes americanus is an important resource species found off the northeast coast of North America. The population consists of numerous local stocks that spawn demersal, adhesive eggs in the different estuaries, bays and offshore banks along the coast (Perlmutter 1947, Saila 1961). Spawning extends from late winter through early spring. After spawning, adults may move offshore to deeper, cooler water but return to the spawning estuary in the fall with a high degree of consistency.

This study was undertaken to examine the variability in size, composition, and survival potential of winter flounder Pseudopleuronectes americanus larvae from different spawning sites, and the relations among these variables. Collection locations were selected to include 
a wide range of urbanization and anthropogenic contamination (Nelson et al. 1991). We determined the size (standard length and dry weight) and chemical composition of winter flounder larvae just prior to feeding initiation and related these data to their survival for the first month of life under standard rearing conditions. In a companion study (Buckley et al. 1991) we examined the factors affecting egg size and fecundity of winter flounder spawning at a single location over the spawning season. This work is part of a larger study on the effects of environmental and parental factors on the size, biochemical composition, and survival potential of winter flounder eggs and larvae.

\section{METHODS}

Adult winter flounder Pseudopleuronectes americanus from Long Island Sound (LIS), New York, USA, were collected with an otter trawl in February 1987 and again in February 1988, and transported live to the NMFS Milford Laboratory, Milford, Connecticut (Nelson et al. 1991). Collection sites were Hempstead, New York; Shoreham, New York; Morris Cove, Connecticut; and Madison, Connecticut (Fig. 1). Fish were held for

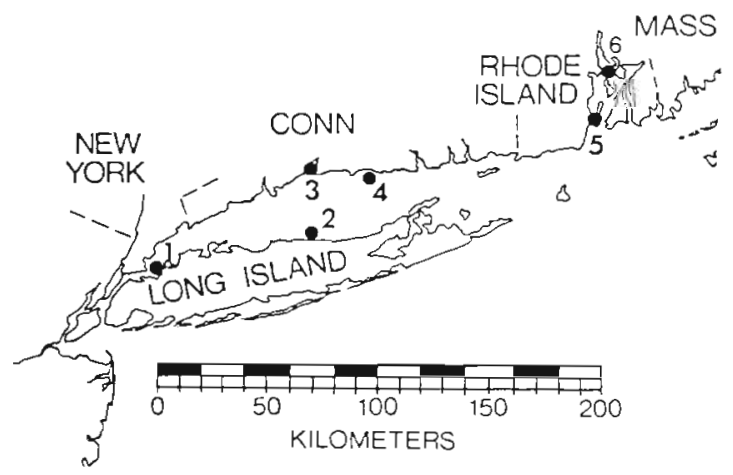

Fig. 1. Collection sites in Long Island Sound and Narragansett Bay, USA. (1) Hempstead, (2) Shoreham, (3) Morris Cove, (4) Madison, (5) lower West Passage Narragansett Bay, (6) upper Narragansett Bay

up to $4 \mathrm{wk}$ in running seawater at ambient temperature $\left(1.0\right.$ to $4.7^{\circ} \mathrm{C}$ ) until ripe. Fish were spawned between 23 February and 20 March 1987 (ambient temperature 1.7 to $4.7^{\circ} \mathrm{C}$ ) and between 9 February and 12 March 1988 (ambient temperature 1.7 to $4.4^{\circ} \mathrm{C}$ ). Eggs were stripped, fertilized, and coated with diatomaceous earth according to techniques developed by Smigielski \& Arnold (1972). Fertilized eggs were transferred to Nitex ${ }^{*}$ mesh baskets and incubated in flowing seawater at ambient temperature until transported to the

\footnotetext{
- Reference to trade names does not imply endorsement by the United States Govermment
}

NMF's Narragansett Laboratory usually within $2 d$ of spawning. Upon arrival at the Narragansett Laboratory, embryos were acclimated to either $7^{\circ} \mathrm{C}$ (1987) or $5^{\circ} \mathrm{C}(1988)$ at the rate of $1^{\circ} \mathrm{C}$ per $6 \mathrm{~h}$.

Adult Pseudopleuronectes americanus, caught in the lower West Passage of Narragansett Bay (NB), Rhode Island, on 9 March 1987, spawned between 10 and 20 March 1987. Fish caught at this site on 11 March 1988 spawned between 12 and 17 March. In 1988 several collections of adult winter flounder were made in upper NB between January and March (Buckley et al. 1991). Only upper NB fish spawning between 13 February and 18 March were used for comparison with other locations, since these dates encompassed the spawning dates for the other areas. Fish were transported to the Narragansett Laboratory and held in flowing seawater at ambient temperature $\left(<8.0^{\circ} \mathrm{C}\right)$. Most fish spawned within $4 \mathrm{wk}$ of capture. Eggs were stripped and handled as described for LIS fish except that embryos were incubated in a constant-temperature room at $7^{\circ} \mathrm{C}$ in 1987 and $5^{\circ} \mathrm{C}$ in 1988. During the 1988 spawning season fertilization and hatch rates were determined as described in Buckley et al. (1991)

Within $3 \mathrm{~d}$ after hatching, duplicate groups of 100 larvae each were transferred to $36 \mathrm{l}$ glass tanks covered on 4 sides with black plastic and set in a constanttemperature room maintained at $7^{\circ} \mathrm{C}$. Tanks contained filtered seawater to which 11 of a dense culture of the unicellular alga Tetraselmis sp. had been added. Tanks were gently aerated and salinities maintained between 28 and $30.5 \%$. When the larvae were first judged capable of feeding, generally on Day 3, any dead larvae were replaced.

In 1987 larvae were fed cultured rotifers (Brachionus plicatilis) and wild plankton at concentrations of 500 rotifers and 500 wild plankters $\mathrm{l}^{-1}$. Rotifers were mass cultured on the alga Tetraselmis sp. Zooplankters were collected in the Narragansett Bay area using 55 and $110 \mu \mathrm{m}$ mesh plankton nets. Only the portion passing through a $210 \mathrm{\mu m}$ mesh was used. This fraction consisted of copepod nauplii, copepodites, and adults in addition to rotifers. Plankton densities were adjusted $6 \mathrm{~d} \mathrm{wk}^{-1}$ back up to 500 rotifers and 500 wild plankters $1^{-1}$. Counts of prey items were made on duplicate $50 \mathrm{ml}$ samples concentrated with a $55 \mu \mathrm{m}$ Nitex screen prior to counting.

In 1988 larvae were fed cultured rotifers (Brachionus plicatilis) at the rate of 2000 rotifers $\mathrm{l}^{-1} \mathrm{~d}^{-1}$ After establishing the density of a rotifer culture, a volume corresponding to 72000 rotifers was concentrated on a sieve and added to each tank $6 \mathrm{~d} \mathrm{wk}^{-1}$ No wild plankton was added and prey counts were not made on the tanks holding the larvae in 1988.

The feeding regime was changed from the earlier protocol in an attempt to raise overall survival rates and 
Table 1 Pseudopleuronectes americanus. Dry weight and biochemical composition of yolk-sac winter flounder larvae produced by adults collected in Narragansett Bay and Long Island Sound, USA, during the 1987 spawning season. Values are means \pm 1 SD. In each row, values with a letter in common are not significantly different (ANOVA, Tukey test, p $\leq 0.05$, SAS Institute Inc 1985). See Fig. 1 for site locations

\begin{tabular}{|c|c|c|c|c|c|}
\hline & Madison & Hempstead & $\begin{array}{c}\text { Site } \\
\text { Shoreham }\end{array}$ & Morris Cove & Narrangansett Bay \\
\hline $\mathrm{n}$ & 6 & 9 & 5 & 7 & 6 \\
\hline Weight (ıg) & $31.9 \pm 2.7 \mathrm{a}$ & $29.4 \pm 3.2 \mathrm{a}, \mathrm{b}$ & $24.8 \pm 4.5 b, c$ & $26.7 \pm 4.1 \mathrm{a}, \mathrm{b}$ & $20.2 \pm 3.5 c$ \\
\hline RNA ( $\mu$ g larva $\left.{ }^{-1}\right)$ & $1.46 \pm 0.15 \mathrm{a}$ & $1.3 \vec{f} \pm 0.19 \mathrm{a}, \mathrm{b}$ & $1.27 \pm 0.15 \mathrm{a}, \mathrm{b}$ & $1.35 \pm 0.19 \mathrm{a}, \mathrm{b}$ & $1.11 \pm 0.13 b$ \\
\hline DNA $\left(\mu g\right.$ larva $\left.{ }^{-1}\right)$ & $0.44 \pm 0.04 \mathrm{a}$ & $0.42 \pm 0.04 \mathrm{a}, \mathrm{b}$ & $0.40 \pm 0.04 \mathrm{a}, \mathrm{b}$ & $0.42 \pm 0.05 \mathrm{a}, \mathrm{b}$ & $0.36 \pm 0.02 b$ \\
\hline Protein ( $\mu g$ larva ${ }^{-1}$ ) & $17.9 \pm 2.4 \mathrm{a}$ & $18.4 \pm 2.6 \mathrm{a}$ & $14.2 \pm 2.9 \mathrm{a}$ & $16.6 \pm 3.0 \mathrm{a}$ & $14.0 \pm 2.0 \mathrm{a}$ \\
\hline Lipid ( $\mu$ g larva ${ }^{-1}$ ) & $4.29 \pm 0.63 a$ & $4.56 \pm 0.51 \mathrm{a}$ & $3.95 \pm 0.53 \mathrm{a}, \mathrm{b}$ & $4.60 \pm 0.77 \mathrm{a}, \mathrm{b}$ & $3.95 \pm 0.53 b$ \\
\hline RNA/DNA & $3.35 \pm 0.17 \mathrm{a}$ & $3.26 \pm 0.19 \mathrm{a}$ & $3.20 \pm 0.11 \mathrm{a}$ & $3.20 \pm 0.23 a$ & $3.05 \pm 0.28 \mathrm{a}$ \\
\hline
\end{tabular}

to facilitate work with larvae from the large number of fish spawned during the 1988 season. In 1987 the wild plankton was observed feeding on the rotifers and there was some concern that survival of the youngest larvae may have been limited by the availability of sufficiently small prey items. Larval survival rates, however, were very similar between years. Because of the changes in the feeding regime and differences in the spawning schedule, no direct comparisons of growth and survival rates were made between years.

After $28 d$ the tanks were drained and the survivors counted, measured, and weighed. Any physical abnormalities were noted at this time.

Initial samples for determination of standard length, dry weight and chemical analysis were taken $3 \mathrm{~d}$ after hatching from stock tanks from which the experimental larvae were removed. Standard lengths were measured on live unpreserved specimens with a filar micrometer in a dissecting microscope. Larvae were rinsed in distilled water, pipetted onto a plastic petri dish, freeze dried and weighed to the nearest $0.1 \mu \mathrm{g}$ on a Cahn automatic electrobalance. During the 1987 spawning season, 3 groups of 50 yolk-sac larvae each were homogenized in $2.0 \mathrm{ml}$ of ice-cold distilled water using an STD Tissumizer mechanical high-frequency homogenizer. Subsamples of $1.4,0.075$ and $0.4 \mathrm{ml}$ of homogenate were used for analysis of nucleic acids, protein and lipid content, respectively. Nucleic acids and protein were determined as described in Buckley (1979). Total lipid content was determined using the sulphophosphovanillin method (Barnes \& Blackstone 1973). Chemical analysis was not performed on larvae from the 1988 spawning season.

Data analysis was done using SAS System software for personal computers (SAS Institute Inc. 1985). Square root transformation was applied to percent survival values $\left[(\text { survival }+0.5)^{1 / 2}\right]$ and arcsine transformation applied to fertilization and viable hatch rates [arcsine $(\% / 100)^{1 / 2}$ ] prior to analysis of variance and regression analysis (Steel \& Torrie 1960).

\section{RESULTS}

\section{7 spawning season}

Eggs were obtained from 7 females from lower NB (Site 5) and 29 females from 4 locations (Sites 1 to 4 ) in LIS (Fig. 1). Fertilization and hatch rates of eggs stripped from LIS fish were variable, ranging from 78 to $93 \%$ and from 45 to $84 \%$, respectively (Nelson et al. 1991). Similar data are not available for Narragansett Bay fish in 1987. Significant differences (ANOVA, $\mathrm{p} \leq 0.05$ ) were observed in the size and chemical composition of newly hatched winter flounder larvae produced by fish collected at the different locations (Table 1). Lower NB fish produced the smallest yolk-sac larvae, while fish collected at the Madison site in LIS produced the largest.

Survival of Pseudopleuronectes americanus from all locations for the first month was low (mean $3 \%$, range 0 to $18 \%$ ) compared to other species of temperate marine fish reared in the laboratory (Buckley et al. 1987). Of the 5 locations studied, survival was lowest for fish from NB, where only 1 larva in 1400 survived for the $28 \mathrm{~d}$ duration of the experiment (Table 2). Among

Table 2. Pseudopleuronectes americanus. Survival of winter flounder for the first month of life during the 1987 spawning season. Values indicate number of females spawned (n), mean larval survival, and mean rank (Wilcoxon score, SAS Institute Inc. 1985) for a given site. Mean ranks with a letter in common are not significantly different ( $\mathrm{p} \leq 0.05$, Kruskal-Wallis test SAS Institute Inc. 1985). See Fig. 1 for site locations

\begin{tabular}{|lccl|}
\hline Site & n & $\begin{array}{c}\text { Survival } \\
(\%)\end{array}$ & Mean rank \\
\hline Madison & 6 & 6.00 & $25.4 \mathrm{a}, \mathrm{b}$ \\
Hempstead & 9 & 4.83 & $26.9 \mathrm{a}$ \\
Morris Cove & 9 & 2.28 & $14.5 \mathrm{~b}, \mathrm{c}$ \\
Shoreham & 5 & 1.50 & $15.2 \mathrm{a}, \mathrm{b}, \mathrm{c}$ \\
Narragansett & 7 & 0.07 & $9.2 \mathrm{c}$ \\
\hline
\end{tabular}


L.IS fish, those from Madison produced the highest percentage of surviving larvae $(6.0 \%)$, while fish from Shoreham produced the lowest $(1.5 \%)$. Analysis of variance of rank scores indicated significant differences $(p \leq 0.05)$ in survival between NB fish and certain of the LIS groups and between the Hempstead and Morris Cove sites in Long Island Sound (Table 2). Daily counts and removal of dead larvae, while not strictly quantitative, suggested that most of the mortality occurred during the second and third weeks. This corresponds to the time of completion of yolk absorption and initiation of feeding at $7^{\circ} \mathrm{C}$ (Buckley 1982). The percentages of surviving larvae that were bent or otherwise malformed were: Hempstead $27 \%$, Shoreham $20 \%$, Madison $8 \%$, and Morris Cove $2 \%$. Surviving larvae from Madison $(6.85 \mathrm{~mm}$ standard length) were the largest after 1 mo of feeding (Table 3),

Table 3. Pseudopleuronectes americanus. Mean length of survivors from the 1987 spawning season. Values indicate number of larvae measured (n) and mean standard length \pm 1 $\mathrm{SD}$. Nean lengths with a letter in common are not significantly different (ANOVA, Tukey test, $\mathrm{p} \leq 0.05$, SAS Institute Inc. 1985). Bent or deformed larvae were not included in the analysis. See Fig. 1 for site locations

\begin{tabular}{|lcc|}
\hline Site & $\mathrm{n}$ & $\begin{array}{c}\text { Standard length } \\
(\mathrm{mm})\end{array}$ \\
\hline Madison & 66 & $6.85 \pm 0.94 \mathrm{a}$ \\
Hempstead & 63 & $6.14 \pm 0.90 \mathrm{a}, \mathrm{b}$ \\
Shoreham & 12 & $6.06 \pm 0.75 \mathrm{~b}$ \\
Morris Cove & 40 & $5.98 \pm 1.48 \mathrm{~b}$ \\
\hline
\end{tabular}

significantly larger than larvae from Shoreham and Morris Cove (ANOVA, $\mathrm{p} \leq 0.05$ ). No evidence of compensatory growth was observd, as the rank order of larval size among spawning locations remained relatively unchanged between hatching and 1 mo of life.

A plot of the mean survival of larvae from a given site against the mean weight of yolk-sac larvae from the same site showed a strong positive relation between these 2 variables (Fig. 2). When data from all locations were combined, significant correlations were observed among percentage survival (S\%), dry weight, and chemical content of larvae shortly after hatching (Table 4). Dry weight of yolk-sac larvae was more highly

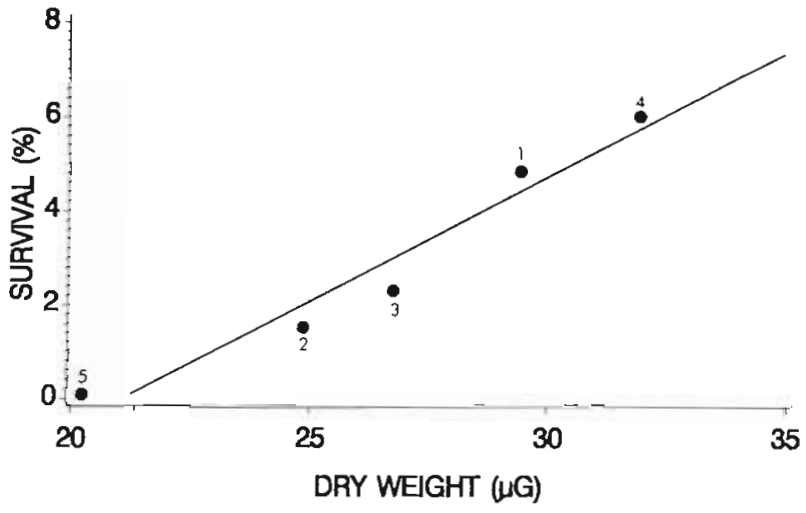

Fig. 2. Pseudopleuronectes americanus. Relation between mean dry weight of yolk-sac larvae and survival for the 1987 spawning season. Points are means for collection sites. (1) Hempstead, (2) Shoreham, (3) Morris Cove, (4) Madison, (5) lower West Passage Narragansett Bay

correlated with survival than was any single class of biomolecules. The relation between $\mathrm{S} \%$ and dry weight $(\mu \mathrm{g})$ of yolk-sac larvae from individual females was described by the equation:

$(\mathrm{S} \%+0.5)^{1 / 2}=(0.116 \times$ weight $)-1.566, \mathrm{n}=31, \mathrm{r}=0.62$

Addition of the content of any single class of biomolecules to the regression model as a second independent variable removed very little of the unexplained variation in survival.

\section{8 spawning season}

Embryos from a total of 23 fish caught at 2 locations in LIS (Madison and Morris Cove) were transported

Table 4. Pseudopleuronectes americanus. Correlations among survival for first 4 wh of life, dry weight, and biochemical content ( $\mathrm{ug}$ larva ${ }^{-1}$ ) of winter flounder within $3 \mathrm{~d}$ of hatchıng. Values are correlation coelficients (n) for the 1987 spawning season. $\mathrm{n}=30$. See Fig. 1 for site locations

\begin{tabular}{|c|c|c|c|c|c|c|}
\hline & Survivai & Weight & RNA & DNA & Protein & Lipid \\
\hline \multicolumn{7}{|l|}{ Survival } \\
\hline Weight & $0.56 \cdots$ & & & & & \\
\hline RNA & $0.43^{\circ}$ & $0.74 \cdots$ & & & & \\
\hline DNA & $0.37^{\circ}$ & $0.73 \cdots$ & $0.91 \cdots$ & & & \\
\hline Protein & $0.40^{\circ}$ & $0.72 \cdots$ & $0.86 \cdots$ & $0.77 \cdots$ & & \\
\hline Lipid & 0.34 & $0.74 \cdots$ & $0.83 \cdots$ & $0.75 \cdots$ & $0.85 \cdots$ & \\
\hline RNA/DNA & 0.32 & $0.46^{\cdots}$ & $0.70 \cdots$ & 0.35 & $0.64^{\cdots} \cdot$ & $0.60^{\cdots}$ \\
\hline \multicolumn{7}{|c|}{$p \leq 0.05, \cdots p \leq 0.01, \cdots p \leq 0.001$} \\
\hline
\end{tabular}


Table 5. Pseudopleuronectes americanus. Size of yolk-sac larvae and viability of winter flounder spawned by fish from Narragansett Bay (NB) and Long Island Sound (LIS), USA, in 1988, Values are means \pm 1 SD. In each column, values with a letter in common are not statistically different (ANOVA, $\mathrm{p} \leq 0.05$ )

\begin{tabular}{|c|c|c|c|c|c|c|c|}
\hline Location & $\begin{array}{c}\text { No. of } \\
\text { females }\end{array}$ & $\begin{array}{c}\text { Female } \\
\text { length } \\
\text { (mra) }\end{array}$ & $\begin{array}{c}\text { Spawning } \\
\text { date } \\
\text { (Julian day) }\end{array}$ & $\begin{array}{c}\text { Initial larval } \\
\text { weight } \\
\text { (g) }\end{array}$ & $\begin{array}{l}\text { Fertility } \\
\qquad(\%)\end{array}$ & $\begin{array}{c}\text { Viable } \\
\text { hatch } \\
(\%)\end{array}$ & $\begin{array}{c}\text { Survival } \\
(\%)\end{array}$ \\
\hline Upper $\mathrm{NB}^{2}$ & 16 & $319 \pm 40$ & $51 \pm 3$ & $29.7 \pm 3.4 \mathrm{a}$ & $92.5 \pm 10.6 a, b$ & $71.7 \pm 21.1 \mathrm{a}$ & $2.6 \pm 2.8 \mathrm{a}, \mathrm{b}$ \\
\hline Lower NB & 9 & $336 \pm 41$ & $74 \pm 1$ & $25.6 \pm 4.4 \mathrm{a}$ & $93.1 \pm 11.8 \mathrm{a}$ & $84.0 \pm 7.0 \mathrm{a}$ & $2.9 \pm 2.2 \mathrm{a}, \mathrm{b}$ \\
\hline Madison, LIS & 9 & $288 \pm 48$ & $68 \pm 3$ & $27.0 \pm 4.8 \mathrm{a}$ & $832 \pm 8.2 b, c$ & $75.8 \pm 11.9 \mathrm{a}$ & $4.8 \pm 4.3 \mathrm{a}$ \\
\hline Morris Cove, LIS & 14 & $315 \pm 42$ & $51 \pm 3$ & $29.5 \pm 4.5 \mathrm{a}$ & $79.4 \pm 13.0 \mathrm{c}$ & $68.8 \pm 17.2 \mathrm{a}$ & $1.4 \pm 2.2 \mathrm{~b}$ \\
\hline
\end{tabular}

from the Milford Laboratory to the Narragansett Laboratory within several days of spawning. Embryos were obtained from 9 females from lower NB. To minimize any effect of spawning time on the results, a subset $(n=16$ ) of the fish spawned from upper NB was used for purposes of comparison with fish from lower NB and LIS. Only fish spawned between Julian Day 44 and 78 were selected, corresponding to the range of spawning dates for the other locations.

No significant difference ( $p \geq 0.05$ ) among sites was observed in viable hatch rates or the weight of yolk-sac larvae (Table 5). Fertilization rate was highest in fish from NB. While no significant difference $(p \geq 0.05)$ in larval survival was observed between NB and LIS fish, survival was significantly higher in the Madison group than the Morris Cove group from LIS (Table 5). No significant correlation was observed between size (standard length or dry weight) of yolk-sac larvae and survival for the first month of life.

\section{DISCUSSION}

The daily mortality rate for winter flounder Pseudopleuronectes americanus larvae in our study averaged $13 \% \mathrm{~d}^{-1}$ for the first month after hatching. Black et al. (1988) reported a value of $4 \% \mathrm{~d}^{-1}$ for winter flounder larvae reared for a period of 2 mo under similar conditions. Laurence (1977) found that prey density had a strong influence on survival of winter flounder to metamorphosis in the laboratory. He reported daily mortality rates of 9 and $7 \% \mathrm{~d}^{-1}$ at prey densities of 500 and 1000 plankters $\mathrm{ml}^{-1}$, feeding levels similar to those maintained in our study. The higher mortality rate observed in the present study may have been due in part to the shorter rearing period that was chosen to encompass the period of high mortality shortly after yolk absorption. Estimates of natural mortality of winter flounder larvae in a small Connecticut estuary were high for the first month of life $\left(20 \% \mathrm{~d}^{-1}\right)$, decreas- ing to $9 \% \mathrm{~d}^{-1}$ during the second month (Pearcy 1962). These estimates of natural mortality included mortality due to starvation and predation, but were corrected for transport of larvae out of the estuary.

For the 1987 spawning season our data show clear differences in size and survival of winter flounder larvae produced by adults collected in different locations in LIS and NB and a correlation between size of yolksac larvae and survival for the first month of life. The range in size of yolk-sac larvae produced during the 1988 spawning season was smaller, and no significant correlation was observed between larval size and survival for the first month of life. While lower NB produced the smallest larvae in both years, the differences in size among groups were not significant in 1988. Some lower NB fish produced extremely small winter flounder larvae in 1987 compared to other years and locations. Black et al. (1988) found differences in size of newly hatched winter flounder between locations in Narragansett Bay and Buzzard Bay, but no significant difference between locations in survival for the first 2 mo of larval life. The differences in size of yolk-sac larvae from different locations observed in our study in 1987 were considerably greater than those reported by Black et al. (1988) and may explain the difference in results.

Correlations between egg size and larval size have been observed in several fishes, including trout (Gray 1928), herring (Blaxter \& Hempel 1963) and winter flounder Pseudopleuronectes americanus (Buckley et al. 1991). Generally, larger eggs produce larger larvae (Miller et al. 1988). Blaxter (1969) stated that larger larvae may be expected to be stronger, better swimmers, less susceptible to damage, and less liable to predation'. It is also expected that larger larvae are better able to capture and assimilate food. Blaxter \& Hempel (1966) found that larger Atlantic herring larvae survived longer without food than those hatched from smaller eggs. Seasonal and regional differences in egg size have been reported for many species (Blaxter \& 
Hempel. 1963, Cushing 1967, Bagenal 1971, Southward \& Demir 1974, Ware 1975, Tanasichuk \& Ware 1987) While positive correlations have been reported between larval size and numerous attributes potentially contributing to increased survival, including days to irreversible starvation, swimming speed, and mouth gape (Knutsen \& Tilseth 1985, Miller et al. 1988), the relation between larval size at first feeding and survival is not well documented, particularly within species. Our data from the 1987 spawning season are among the few published reports showing a direct correlation between larval size and survival for the first month of life. Rosenberg \& Haugen (1982) found evidence of size-selective mortality of larval turbot Scophthalmus maximus during the first month of life in predator-free enclosures. Their estimates of the mean size of survivors were higher than those for the overall population during the first week of life.

Several factors have been proposed as possible causes of intraspecific differences in egg or larval size. Many of these same factors can also contribute to differential larval mortality. Biological factors that affect larval size and mortality include genetic variability between and within stocks, and size, age or nutritional condition of the spawning female (Brown 1957, Hoar 1957). Environmental factors known to affect larval size and mortality are water temperature during gametogenesis and embryonic development (Blaxter \& Hempel 1963, Bagenal 1971, Southward \& Demir 1974, Ware 1975, Tanasichuk \& Ware 1987, Buckley et al. 1990), dissolved oxygen levels, and exposure to environmental contaminants, including PCBs, pesticides, and heavy metals (Rosenthal \& Alderdice 1976 Black et al. 1988).

The difference in mean dry weight of yolk-sac larvae, observed in 1987, between the largest and smallest groups (Madison in LIS and lower NB) was large, exceeding $50 \%$. Since Pseudopleuronectes americanus populations consist of discrete spawning stocks (Perlmutter 1947. Saila 1961), genetic factors may have contributed to the observed variability in size and survival between locations. The much smaller differences between locations observed in 1988, however, suggest that genetic factors may not be dominant. Winter flounder fed reduced rations in the laboratory showed a reduction in fecundity but not egg size compared to well-fed fish (Tyler \& Dunn 1976), suggesting that maternal nutrition is not a dominant factor in determining egg and larval size in winter flounder. Female age has been shown to affect egg size in winter flounder (Topp 1968), age 3 females producing smaller eggs than age 4 or 5 females. Our work with winter flounder spawning in Narragansett Bay (Buckley et al. 1991) suggested that female size can play a significant role in determining egg and larval size. In the present study no large difference in female size was apparent between locations. In 1987 lower Narragansett Bay fish were the last group collected and spawned, and they produced the smallest larvae. Among spring spawning fish there is a tendency for egg size to decrease with increasing water temperature. The observed 50\% difference in size of yolk-sac larvae between locations is considerably greater than the differences observed among winter flounder larvae produced in the laboratory over a wide range of water temperatures by adults collected at a single location (Buckley et al. 1990). This suggests that while water temperature may have been a contributing factor, it was not the dominant factor affecting larval size in the present study. Our data on winter flounder spawning in Narragansett Bay indicated that spawning time can play a significant role in egg and larval size (Buckley et al. 1991).

Of our 6 collection sites, the Morris Cove, Hempstead, and upper Narragansett Bay sites are impacted by a variety of contaminants, including trace metals and organics (Greig et al. 1977, Pruell \& Quinn 1985). The Madison, Shoreham and lower Narragansett Bay sites are considerably less impacted by contaminants (Greig et al. 1977. Pruell \& Quinn 1985, Black et al. 1988, Nelson et al. 1991). The observed trends in size and survival of winter flounder with location were not entirely consistent with those expected on the basis of contaminant loadings. However, among sites in Long Island Sound, Madison stood out in 1987 as producing the largest larvae at yolk-sac stage and after 1 mo of feeding, and as having the highest survival rate and a low percentage of abnormal survivors. In both 1987 and 1988 survival was higher in larvae from Madison than from Morris Cove. This is consistent with observations of embryonic development suggesting that reproduction of winter flounder at the Morris Cove site has been compromised by high contaminant levels (Nelson et al. in press). Black et al. (1988) reported an 18\% difference in weight of yolk-sac winter flounder larvae produced by adults taken from lower Narragansett Bay and New Bedford Harbor, Massachusetts. Larvae from New Bedford Harbor fish were smaller and their eggs contained significantly higher levels of PCBs. A significant inverse relation was observed between larval size and PCB content.

No single class of biomolecules appared elevated in groups of larvae with high dry weight or high survival. Contents of all classes of biomolecules measured were highly correlated with each other and with larval dry weight (Table 4). In 1987 dry weight of yolk-sac larvae was more highly correlated with survival than was any single class of biomolecules. The RNA/DNA ratio has been used as an index of growth and condition in fish (Buckley 1984, Bulow 1987). No significant correlation was observed between the RNA/DNA ratio of yolk-sac 
winter flounder larvae and survival for the first month of life (Table 4). This was apparently due to the high correlation between RNA and DNA content, and the unique situation of larvae prior to feeding initiation, when they rely on endogenous energy reserves of maternal origin. The RNA content or simply the dry weight of yolk-sac larvae appear to be useful indicators of the survival potential of winter flounder through the critical first month of life.

In 1987 survival of Pseudopleuronectes americanus for the first month of the larval period was highly correlated with both size and chemical composition of larvae shortly after hatching. The correlation between size and survival of winter flounder larvae may have been, in part, due to a wider size spectrum of prey items available to larger larvae in our experimental systems. Larger larvae, because of their wider mouth gape, effectively experience a higher level of available food. This factor may be important for both laboratoryreared and wild larvae. It is possible that the lower viability of small larvae may be offset by increased fecundity (Buckley et al. 1991).

While both biological and environmental factors may have contributed to the observed differences in size and survival among larvae produced by Long Island Sound and Narragansett Bay winter flounder, we could not identify a single dominant factor. Our data on winter flounder spawning in Long Island Sound and Narragansett Bay (Buckley et al. 1991) suggest that female size and spawning time can have important effects on egg and larval size, fecundity, and spawning survival potential.

\section{LITERATURE CITED}

Bagenal, T L. (1971). The interrelation of the size of fish eggs, the date of spawning and the production cycle. J. Fish Biol. 3: $207-219$

Barnes, H., Blackstone, J. (1973). Estimation of lipids in marine animals and tissues: detailed investigation of the sulphophosphovanillin method for 'total' lipids. J. exp. mar. Biol. Ecol. 12: 103-118

Black, D. E., Phelps, D. K., Lapan, R. L. (1988). The effects of inherited contamination on egg and larval winter flounder, Pseudopleuronectes americanus. Mar. environ. Res. 25: $45-62$

Blaxter, J. H. S. (1969). Development: eggs and larvae. In: Hoar, W. S., Randall, D. J. (eds.) Fish physiology. Academic Press, New York, p. 177-252

Blaxter, J. H. S., Hempel, G. (1963). The influence of egg size on herring larvae (Clupea harengus L.). J. Cons perm. int. Explor. Mer 28: 211-240

Blaxter, J. H. S. Hempel, G. (1966). Utilization of yolk by herring larvae. J. mar. Biol. Ass. U.K. 46: 219-234

Brown, M. E. (1957). Experimental studies on growth Chap. IX. In: Brown, M. E. (ed.) The physiology of fishes. Academic Press, New York, p. 361-400

Buckley, L. J. (1979). Relations between RNA-DNA ratio, prey density, and growth rate in Atlantic cod (Gadus morhua) larvae. J. Fish. Res. Bd Can. 36: 1497-1502

Buckley, L. J. (1982). Effects of temperature on growth and biochemical composition of larval winter flounder Pseudopleuronectes americanus. Mar. Ecol. Prog. Ser 8: 181-186

Buckley, L. J. (1984). RNA-DNA ratio: an index of larval fish growth in the sea. Mar. Biol. 80: 291-298

Buckley, L. J., Halavik, T A., Smigielski, A. S., Laurence, G. C. (1987). Growth and survival of the larvae of three species of temperate marine fishes reared at discrete prey densities. Am. Fish. Soc. Symp. 2: 82-92

Buckley, L. J., Smigielski, A. S., Halavik, T A., Caldarone, E. M., Burns, B. R., Laurence, G. C. (1991). Winter flounder Pseudopleuronectes americanus reproductive success. II. Effects of spawning time and female size on size, composition and viability of eggs and larvae. Mar. Ecol. Prog. Ser $74: 125-135$

Buckley, L. J., Smigielski, A. S., Halavik, T. A, Laurence, G. C. (1990). Effects of water temperature on size and biochemical composition of winter flounder Pseudopleuronectes americanus at hatching and feeding initiation. Fish. Bull. U.S. 88: 419-428

Bulow, F. J. (1987). RNA-DNA ratios as indicators of growth in fish: a review. In: Summerfelt, R. C., Hall, G. E. (eds.) Age and growth of fish. Iowa State University Press, Ames, p. 45-64

Cushing, D. H. (1967). The grouping of herring populations. J. mar. biol. Ass. U.K. 47: 193-208

Cushing, D. H. (1975). Marine ecology and fisheries. Cambridge University Press, Cambridge

Gray, J. (1928). The growth of fish. II. The growth-rate of the embryo of Salmo fario. J. exp. Biol. 6: 110-124

Greig, R. A., Reid, R., Wenzloff, D. (1977). Trace metal concentrations in sediments of Long Island Sound. Mar. Poltut. Bull. 8: 183-188

Hoar, W. S. (1957). The gonads and reproduction, Chap. VII. In: Brown, M. E. (ed.) The physiology of fishes. Academic Press, New York, p. 287-321

Houde, E. D. (1987). Fish early life dynamics and recruitment variability. Am. Fish. Soc. Symp. 2: 17-29

Hunter, J. R. (1981). Feeding ecology and predation of marine fish larvae. In: Lasker, R. (ed.) Marine fish larvae: morphology, ecology and relation to fisheries. Washington Sea Grant Program. Univ. of Washington Press, Seattle, p. 33-37

Knutsen, G. M., Tilseth, S. (1985). Growth, development, and feeding success of Atlantic cod larvae Gadus morhua related to egg size. Trans. Am. Fish. Soc. 114: 507-511

Laurence, G. C. (1977). A bioenergetic model for the analysis of the feeding and survival potential of winter flounder, Pseudopleuronectes americanus, larvae during the period from hatching to metamorphosis. Fish. Bull. U.S. 75: $529-546$

Miller, T. J., Crowder, L. B., Rice, J. A., Marschall, E. A. (1988). Larval size and recruitment mechanisms in fishes: toward a conceptual framework. Can. J. Fish. Aquat. Sci. 45: $1657-1670$

Nelson, D. A., Miller, J. E., Rusanowsky, D., Greig, R. A., Sennefelder, G. R., Mercaldo-Allen, R., Kuropat, C., Gould, E., Thurberg, F. P., Calabrese, A. (1991). Comparative reproductive success of winter flounder in Long Island Sound and Boston Harbor a 3-year study (biology, biochemistry, and chemistry). Estuaries

Pearcy, W. G. (1962). Ecology of an estuarine population of winter flounder phytoplankton (Walbaum). Bull. Bingham Oceanogr. Coll. 18: 5-78

Perlmutter, A. (1947). The black back flounder and its fishery in New England and New York. Bull. Bingham oceanogr Coll. 11: 1-92 
Pruell, R. J., Quinn, J. G. (1985). Geochemistry of organic contaminants in Narragansett Bay sediments. Estuar. coast. shelf Sci. 21: 195-312

Rosenberg, A. A., Haugen, A. S. (1982). Individual growth and size-selective mortality of larval turbot (Scophthalmus maximus) reared in enclosures. Mar. Biol. 72: 73-77

Rosenthal, H., Alderdice, D. F. (1976). Sublethal effects of environmental stressors, natural and pollutional, on marine fish eggs and larvae. J. Fish. Res. Bd Can. 33: 2047-2065

Saila, S. B. (1961). A study of winter flounder movements Limnol. Oceanogr 6: 292-298

SAS Institute Inc. (1985). SAS/STAT guide for personal computers, Version 6 edn. SAS Institute, Inc., Cary, North Carolina

Smigielski, A. S., Arnold, C. R. (1972). Separating and incubating winter flounder eggs. Progve Fish Cult. 34: 113

Southward, A. J., Demir, N. (1974). Seasonal changes in dimensions and viability of the developing eggs of the cornish pilchard (Sardinia pilchardus walbaum) off Plymouth. In: Blaxter, J. H. S. (ed.) The early life history of fish. Springer-Verlag, New York, p. 53-68

This article was presented by $K$. Sherman. Narragansett, Rhode Island, USA
Steel, R. D. G., Torrie, J. H. (1960). Principles and procedures of statistics. McGraw-Hill, New York

Tanasichuk, R. W., Ware, D. M. (1987). Influence of interannual variations in water temperature on fecundity and egg size in Pacitic herring (Clupea harengus pallasi). Can. J. Fish. Aquat. Sci. 44: 1485-1495

Topp, R. W. (1968). An estimate of the fecundity of winter flounder, Pseudopleuronectes americanus. J. Fish. Res. Bd Can. 25: 1299-1302

Tyler, A. V., Dunn, R. S. (1976). Ration, growth, and measures of somatic and organ condition in relation to meal frequency in winter flounder, Pseudopleuronectes americanus, with hypotheses regarding population homeostasis. J. Fish. Res. Bd Can. 33: 63-75

von Westernhagen, H. (1988). Sublethal effects of pollutants on fish eggs and larvae. In: Hoar, W S., Randall, D. J. (eds.) Fish physiology, Vol. XI, The physiology of developing fish, Part A, Eggs and larvae. Academic Press, San Diego, p. 253-346

Ware, D. M. (1975). Relation between egg size, growth, and natural mortality of larval fish. J. Fish. Res. Bd Can. 32: $2503-2512$

Manuscript first received: December 3,1990

Revised version accepted: May 21, 1991 